\title{
Challenges and Opportunities: Intercultural Approaches in Chinese College ELF Reading Class
}

\author{
Wang $\mathrm{Xi}^{*}$ \\ *Author: Wang Xi, (1985-) ,College of Humanity, Beijing University of Chinese Medicine. \\ 13717703323@163.com
}

\section{Keywords: Intercultural Approaches, ELF, College English, Reading Class}

\begin{abstract}
In the modern globalization context, China has been experiencing increasingly frequent international communications, which urges improvements in college English education. How to cultivate a large number of talents with international vision poses new tasks to the teachers. As the most common lesson type in college English as foreign language classes, reading is significant in developing students' different aspects of language knowledge and ability. However, many teachers believe it is difficult to create learners' autonomy, communication and intercultural vision with this lesson type. In fact, in reading classes, intercultural teaching approaches are challenging but also opportunities to optimize students' learning outcomes. I would review its related theories and strategies, identify issues that could be strengthened by it in my teaching college English reading, link the theories to China's national context of college EFL reading classes, and suggest ways to make improvements.
\end{abstract}

\section{Introduction}

According to Kramsch (2010), intercultural language teaching is an approach that makes the relationships between different cultures visible for students. Students can also critically and analytically understand different cultures with this approach. The assumption of ILT is that language is a part of culture, which is invisible and need to be learned. According to Scarino and Liddicoat (2009), this approach aims to promote capability to negotiate meanings across cultures in a globalization context. This approach has been widely accepted in Australia since its National Statement and Plan for Languages Education in Australian Schools 2005-2008 was released (Mceetya, 2007). However, according to Liddicoat (2008), there is still no agreement on what cultural aspects and how deeply they should be taught by teachers with this approach. But one point agreed on by most people is to develop students' cultural competence by teaching them how to engage with culture, not only how to remember it.

The strategies suggested by various studies are illuminating. Kramsch (2009) recommended teachers to adopt communicative activities to lead students to reflect on discourse and communication, the hidden meanings and ambiguities in the texts. The students' emotion was also advised to be emphasized besides their cognition. Wang (2010) suggested teachers deeply studying the cultural aspects in language so as to better lead students to discover the ideology, value, and custom beneath the reading texts. Moreover, it is important to ensure students' understanding of the texts' language, on which the acquisition of intercultural knowledge is based. She also argued the intercultural teaching should not just stay in the stage of understanding culture, but make students learn to compare different cultures. Therefore, the students need to better understand their own culture especially in the language texts firstly, which can benefit their studying the target culture in the language texts and making comparison of the two.

\section{Teaching application}

In my own teaching of college English reading, I also feel the students' intercultural competence needs to be improved. On one hand, the present college exam system has put little emphasis on the 
intercultural aspects of English language, especially in the reading tests. This causes some students' neglecting of much important intercultural knowledge in their learning reading texts. It also provides difficulties for my teaching the intercultural knowledge in reading classes because even of the students are interested in culture they may not take it as seriously as the language knowledge, which undermines their intercultural competence development. On the other hand, in many students' mind, the English culture refers to American culture in which everything is superior and fashionable. However, they often have critical ideas on some Chinese cultures. So the students' lack of critical competence to view the American culture can attribute to their lack of objective and deep understanding of the foreign culture.

In the Chinese national context, this problem also exists in the college English reading classes. Wang (2010) illustrated several difficulties. On one hand, the students' language competence is still not good enough to support their development of intercultural competence. As language is the container of culture, if students can not well understand the reading discourse in the context, they will not appropriately acquire the intercultural knowledge. But too much emphasis on language also reduces the effort on intercultural considerations. On the other hand, the present Chinese national CET exams' little attention on assessing students' intercultural competence causes both teachers and students' not taking intercultural knowledge seriously enough. In China's college English reading classes, many teachers spend a lot of time in teaching the grammar and vocabulary but often neglect integrating the intercultural knowledge and developing the students' intercultural competence, and many students do not probe deeply into the intercultural knowledge beneath the texts during reading.

Therefore, I would like to provide some suggestions for this approach's implementation in China's college English reading class. First, the national CET exams should put more emphasis on the students' intercultural competence assessing, especially in the reading section. The intercultural knowledge is as significant as the language knowledge in real language using, so it is important to motivate students and teachers to better implement this approach. Second, when the teachers prepare the lessons, they should better explore the intercultural issues beneath the reading texts, as well as design meaningful context so as to better motivate the students to develop their intercultural competence, such as through the multimedia (Xu, 2009). Third, the teachers should balance their teaching of the language knowledge and the intercultural knowledge. And intercultural competence development should be based on particular class' teaching objectives (Wang, 2010). Moreover, activities such as the group project on critical discourse analysis can be adopted to engage learners.

As we can see, the intercultural language teaching is challenging but very important for China's college English reading classes. The intercultural language teaching approach can well promote students' learning autonomy as well as develop their communicative competence. First, development of students' intercultural competence can improve their language ability. Successful teaching of the intercultural language knowledge can help students to enlarge eyesight and develop critical thinking, as well as stimulate their interests in studying the language and investigating the hidden intercultural meanings. This could motivate students and promote their language leaning autonomy. Second, students' intercultural knowledge is significant for their using English to communicate in the real contexts. In English reading classes for example, if students do not have sufficient intercultural knowledge, they possibly have difficulties to understand the texts, do not mention communicating with author, teacher and classmates. On the contrary, good intercultural knowledge can help explain some language phenomenon in the reading texts, so as to promote better communication. Thus, developing students' intercultural knowledge is important for their learning autonomy and meaningful communication in English reading classes.

\section{Discussion}

Therefore, I would like to recommend some suggestions. First, increase the reform of China's CET system. The new exam system should develop the assessment of students' communicative competence as well as their intercultural competence, so as to better motivate the teachers and students. This is one important way to promote college students' leaning autonomy. Second, the 
college English textbooks should adopt more authentic yet simple texts that contain rich intercultural meanings. The students are interested in the authentic texts because they provide a real learning context, which is often more interesting or meaningful. However, the authentic language produced by real speakers is more difficult for learning (Gilmore, 2007). So the textbook editors need to search some relative simple texts with really useful language that can be well accepted by the learners. The teachers also need to design simple communicative tasks to engage students. In this way, the college English reading classes can have more efficient teaching to cultivate students' communicative and intercultural competence. Third, the teachers should make clear decision on their reading classes' outcomes. What language knowledge needs to be taught and what intercultural knowledge needs to be learned in one class should all be considered. Never hesitate to give the class back to students and let them fully engage and present themselves in meaningful communicative activities.

\section{Conclusion}

In the modern context of internationalization, China needs to cultivate more talents who have not only good English language knowledge, but also excellent communicative and intercultural competences. These are challenges as well as opportunities for the Chinese college English reading class.

To better turn the challenges into opportunities, we need to adopt innovative ideas and work together to improve the present teaching and learning. As in our college English reading classes, the assessment methods, the reading textbooks, the teachers' attitudes and teaching methods, as well as the students' attitudes and learning habits all attribute to this critical turning. Therefore, we should critically reflect on them, and take scientifically measures to make reforms on them, so as to better develop students' intercultural competences in our college English reading classes. In this way, we can cultivate talents who have full-scale English language knowledge, and are competitive in the world.

\section{References}

[1] Gilmore, A. (2007). Authentic materials and authenticity in foreign language teaching. Language Teaching, 40, 97-118.

[2] Kramsch, C. (2009). The multilingual subject. What foreign language learners say about their experience and why it matters. Oxford: Oxford University Press.

[3] Kramsch, C. (2010). The symbolic dimensions of the intercultural. Language Teaching, 36, $1-14$.

[4] Liddicoat, A. J. (2008). Language choices in the intercultural classroom: Considering possibilities for communication and learning. Babel, 43, 35-38.

[5] Mceetya (2007). National assessment program ICT literacy years 6 and 10 report, 2005. Australia: MCEETYA.

[6] Scarino, A., \& Liddicoat, A. J. (2009). A guide: Teaching \& learning languages. Carlton South, Vic.: Curriculum Corporation.

[7] Wang, D. X. (2010). Analysis of present status and strategies of cross-cultural language teaching. Journal of Dalian University, 4, 124-126.

[8] Xu, H. (2009). The cultivation of intercultural communicative competence in college English teaching. China Adult Education, 12, 131-132. 